Historical Changes of Regulation and Competition in British Railway System

\title{
Hanyu Zhao
}

Great Wall Glory Securities, Beijing 100071, China

DOI: $10.32629 /$ memf.v2i6.592

Abstract: This article is based on the history of British railway reform, combined with related theories and policies, and explored what kind of regulatory policies should be adopted in what kind of economic environment.

Keywords: British railway, regulatory policy, reform

\section{The role of railways in the economy}

Railways have a fundamental role in the economy. It is the main artery of the national economy and has public attributes. The first railway in the world was built in Britain in September 1825. However, British railways have undergone decades of tortuous reforms. By analyzing the reform path of British Railways, we can understand what kind of regulatory policies should be adopted in what kind of economic environment.

\section{The concept of monopoly}

The basic feature of natural monopoly is to achieve increasing returns to scale within a certain range of output (Clarkson et al., 1982). Generally speaking, the sunk costs of natural monopoly industries are relatively large. At this time, the entry of new enterprises will inevitably bring cost pressures to the production of old enterprises, and price competition will lead to a decline in the normal profits of enterprises, which is not conducive to the development of enterprises. (Foster, et al, 1994).

\section{History of British railways}

Britain is the originator of world rail transportation. In 1880, the main line was basically completed. After the merger of private railways in 1923, British Railways gradually became a monopoly in the transportation industry. In 1948, the state-owned enterprise "British Railways" (BR) was established, and the British Railways Bureau (BRB) was established. However, with the emergence of roads and the development of aviation, railway transportation has gradually lost its dominant position. In the four years from 1952 to $1992,30 \%$ of passenger lines and $40 \%$ of freight lines were closed, and the passenger rail market share dropped from about $20 \%$ to $5.6 \%$ (Bill, 1996). To solve this problem, BR carried out two structural reforms

in 1982 and 1988. The market-oriented reforms began in 1994.

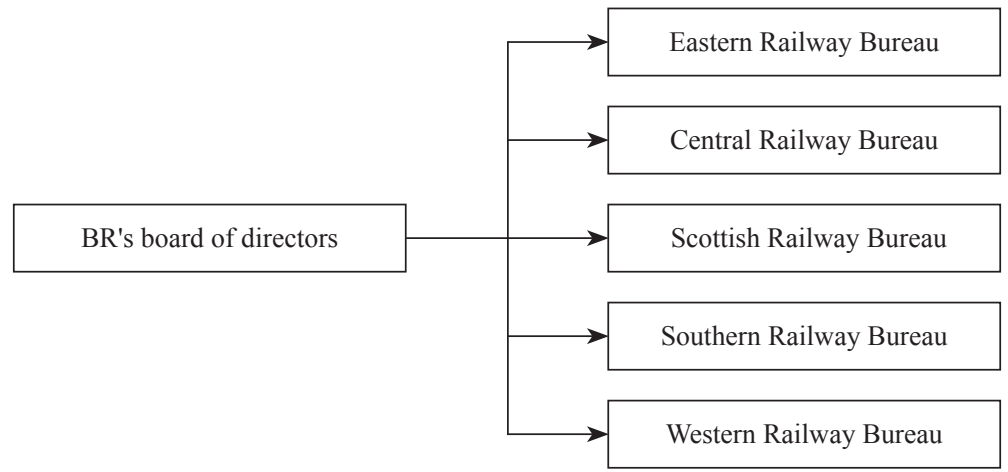

Figure 1. BR structure chart (before the internal reform)

\section{Reasons for failure and reform measures}

\subsection{Reasons for failure}

When it comes to the reasons for the failure of the nationalization of the British National Railways, traditional views believe that railways have a typical natural monopoly. At the same time, according to the theory of public goods and 
externalization, railways have strong public goods attributes and large externalities, which are called " Public welfare". Therefore, for a long time, many countries have defined the social and economic attributes of the railway industry as natural monopoly and public welfare, and classified the entire railway industry as "market failure".

But in fact, the railway industry is not a whole natural monopoly, but a "partial natural monopoly." "Since 1994, the market reform of British Railways has been mainly based on the theory of competitive markets.

\subsection{Reform measures}

In 1994, the British Railways implemented the "separation of network and transportation". In 1997, British railways underwent a comprehensive reform. The British government has established the Railway Passenger Transport Concession Office (OPRAF) and the Railway Regulatory Office (ORR). In addition to the various transactions between the passenger transport franchise and railway enterprises, ORR supervision is also responsible for overall supervision. Other regulatory agencies, such as the Railway User Advisory Committee (RUCC) and the Railway Inspector General (HMRI), are responsible for protecting the interests of railway users and representing their opinions.

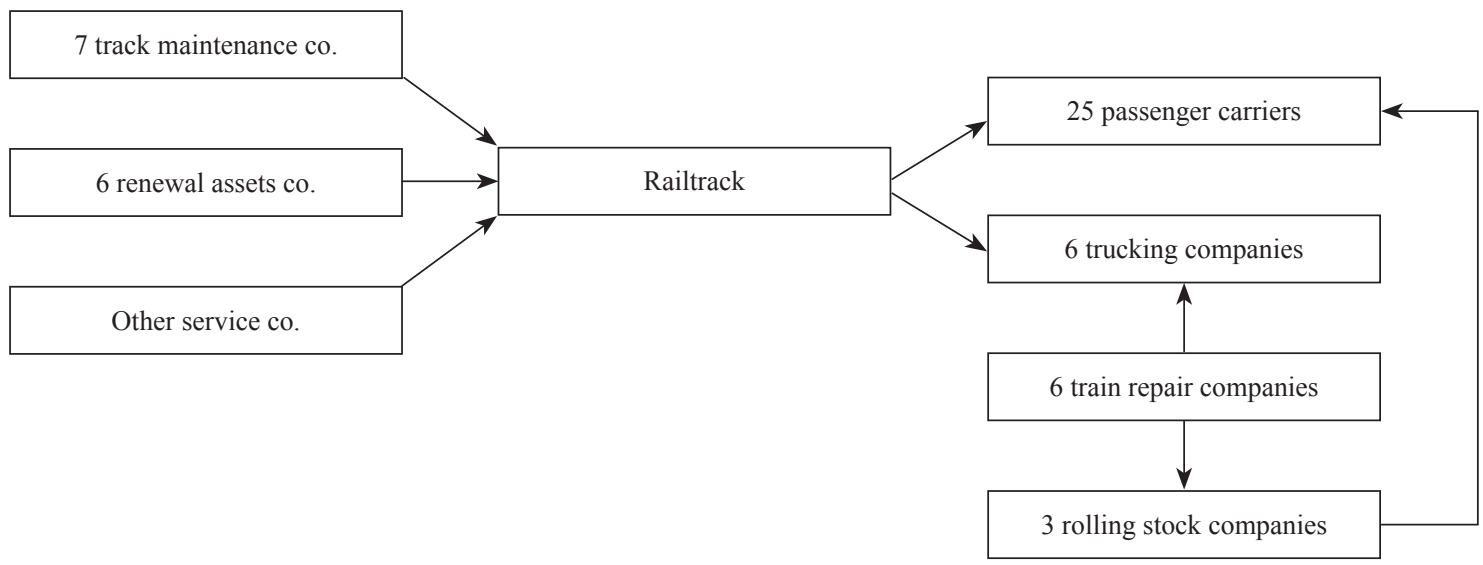

Figure 2. The structure of British railway industry after privatization (Ps: The arrow direction is the direction of service provision)

It can be seen from the reform measures of the British government that the first basic idea of its reform is to separate the "road network", that is, to separate the natural monopoly line from the non-natural monopoly operation and build a competition platform. The second is to diversify the competitors and avoid the formation of bilateral monopolies. The third is to resolve entry and exit barriers, reduce sunk costs, and improve competitiveness.

First, due to the introduction of the competition mechanism, various railway companies have increased their investment and implemented a system of survival of the fittest for their employees. (See Table 1)

Table 1. Statistics of British railway traffic volume from 1994-2000

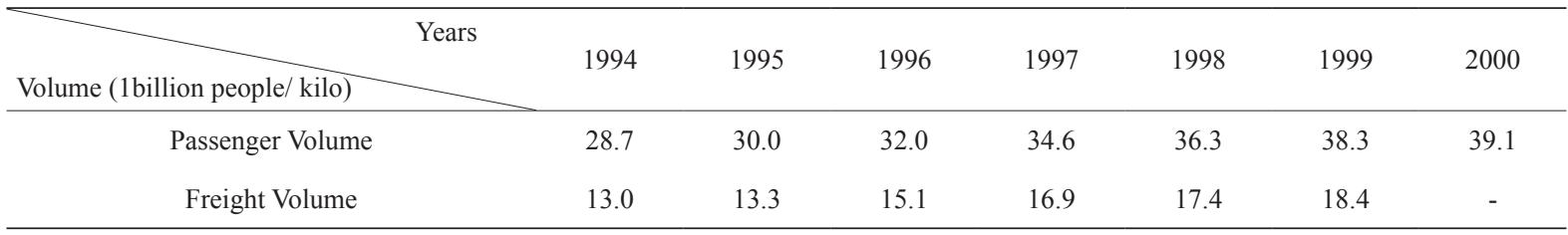

The second is the decrease in government financial subsidies, and the increase in private investment has alleviated the pressure on the government's finances. It can be seen from Table 2 that private investment has increased year by year, while government public investment and government subsidies have shown an overall downward trend.

Table 2. Public investment, private investment, financial subsidies of British railways from 1992 -2000 (unit: 100 millions pounds)

\begin{tabular}{cccccccccc}
\hline Sort & Years & 1993 & 1994 & 1995 & 1996 & 1997 & 1998 & 1999 & 2000 \\
\hline & & 0 & 1 & 1 & 12 & 17 & 20 & 35 \\
Private investment & 18 & 29 & 27 & 8 & 8 & 7 & 6 & 5 \\
Public investment & 9 & 18 & 17 & 18 & 14 & 12 & 10 \\
Financial subsidy & & & &
\end{tabular}


There is no doubt that the reform of privatization of British railways has made many achievements, but it has also produced many problems. On the one hand, companies ignore railway infrastructure investment. On the other hand, the government lacks effective investment plans and strategies. In addition, road network companies pay little attention to infrastructure maintenance and traffic quality, leading to frequent safety incidents (Gómez, 1993). In addition, a mature control system is essential for the introduction of competition and privatization of railways.

The restructuring and nationalization of British Railways has injected new vitality into the development of British Railways. The Railway Administration's "2009-2014 Railway Development Plan" includes: railway development strategy and transportation market demand forecasts. In terms of railway construction, the government has focused on increasing railway construction, such as the High Speed Rail Line 1 and London Transit Railway.

\section{Reflection}

Looking back at the railway reform in the UK for decades, we can find that its main purpose is to break the monopoly and improve the operating efficiency of the railway transportation industry. However, as the economy recovered after World War II, the shortcomings of state-owned railways were exposed. Although British Railways has carried out two internal reforms, the effect is not satisfactory. The railway privatization reform has indeed brought surprises to the British government. However, the frequent occurrence of railway traffic accidents has made the government realize that the operation and development of the railway industry cannot be separated from the government's macro-control.

Under such circumstances, the government has continuously improved its functions, clarified the boundary between the government and the market, reorganized the road network companies, and adjusted the regulatory agencies. It can be seen from this that for the more special public industries such as railways, the government must scientifically plan and improve supervision, but it must not intervene too much and affect the normal operation of enterprises. Therefore, the key to improving the efficiency and effectiveness of public utilities lies in the government creating a market-oriented environment, introducing competition, and then scientifically monitoring to ensure the sustainable development of public utilities. Therefore, competition and regulation do not conflict to some extent.

\section{References}

[1] Baumol, W., Panzar, J., \& Willig, R. 1982. Contestable markets and the theory of industry structure. New York: Harcourt Brace Jovanovich, Inc.

[2] Bill Bradshaw. 1996. The Privatization of Railways in Britain. Japan Railway and Transport Review, (8): 15-21.

[3] Bowman, A. 2015. An illusion of success: The consequences of British rail privatisation. Accounting Forum, 39(1): 51-63. Available from: https://doi.org/10.1016/j.accfor.2014.10.001

[4] Foster, C. (1992). Privatization, public ownership, and the regulation of natural monopoly. Oxford: Blackwell.

[5] Foster, C., Boettke, P., Foster, C., \& Boettke, P. 1994. Review of Privatization, public ownership and regulation of natural monopoly. Journal of economic literature, xxxii(4): 1916-1918.

[6] Gómez-Ibáñez, J., \& Meyer, J. 1993. Going private : the international experience with transport privatization. Washington, D.C: The Brookings Institution.

[7] Headicar, P. 2009. Transport policy and planning in Great Britain. London: Routledge.

[8] Jams tomorrow. 1993. Transportation policy in Britain (Editorial). The Economist (US), 326(7801): 16-17.

[9] Jones, I. 2000. Developments in transport policy - The evolution of policy towards on-rail competition in Great Britain. Journal of Transport Economics and Policy, 34(3): 371-384. Available from: http://search.proquest.com/ docview/217075722/

[10] MERCER. 2002. The GB Rail Industry: In its own words. Problems and Solutions. London: Department for Transport.

[11] Merkert, R. 2005. The restructuring and future of the British Rail system. Institute of Transport Studies, University of Leeds, Leeds, UK.

[12] Thompson, L. 2004. Privatizing British Railways: Are There Lessons for the World Bank and its Borrowers? World Bank, Washington, DC. 